\title{
The effect of soil compaction at various depths on root and shoot growth of oats
}

\author{
J. J. Schuurman and J. J. H. de Boer \\ Institute for Soil Fertility, Haren (Gr.), the Netherlands
}

Accepted: 21 June 1974

\section{Summary}

An experiment was carried out to study the response of root development of oats on the presence of soil compaction at various depths. For this purpose artificial profiles were used of sandy soil with a humus percentage of 4.2 , having a loose topsoil of 23 , 43 or $63 \mathrm{~cm}$, respectively, on a dense subsoil of 75,55 or $35 \mathrm{~cm}$. Root and shoot development on these profiles were compared with those in a homogeneous loose profile with a height of $98 \mathrm{~cm}$ (Fig. 1-3). Root weights were calculated at $5 \mathrm{~cm}$ increments in five stages of growth (Fig. 4). Shoot weights were more or less identical in the early stages but were highest in the two profiles with the thinnest loose topsoil in the later stage (Table 1 ). This was roughly paralleled by the root weights (Table 2). Through the whole growth period the root weights in the loose topsoil of the heterogeneous profiles were higher than in the comparable layers of the homogeneous ones. Those in the dense subsoil of the heterogeneous profiles were lower than in the corresponding loose subsoil of the homogeneous ones. Up to 23 May total root weights were highest in the homogeneous profiles, after that date this was the case in the heterogeneous ones. This was caused by a considerably higher increase of root weights in the upper portions of the heterogeneous profiles as compared with the corresponding layers of the homogeneous ones (Fig. 5). Rooting depth was restricted according to the depth of the dense subsoil.

Root weights decreased considerably more at the transition from loose to dense soil than in the corresponding layers of the homogeneous profile (Table 3). Numbers of root axes decreased also but to a lesser extent (Table 4). This leads to the conclusion that decreases in root weight were caused to a certain extent by diminution in root numbers but for the major part by decreases in root branching. The available data did not allow for a conclusion whether this was a question of smaller numbers of branch roots or shorter ones or both.

Rooting depth in the dense subsoil was generally speaking deeper as the thickness of the loose topsoil was smaller. The ultimate maximum penetration was probably also influenced by depth of the water-table, especially in the profiles with 23 and $43 \mathrm{~cm}$ loose topsoil.

Shoot/root ratios in the subsequent growth stages were highest in the profiles with a loose topsoil of 23 and $43 \mathrm{~cm}$ (Fig. 6), indicating that growth conditions were most favourable in these profiles notwithstanding the restricted root development (Fig. 4). This was confirmed by the water consumption. 


\section{Introduction}

In the course of the last decennium the influence of soil compaction on the growth of roots and shoots of oats has been studied (Schuurman, 1965, 1968, 1971a, b; Schuurman \& de Boer, 1971). It was found that root growth was less extensive in homogeneous profiles as soil density was higher and that it also decreased at the transition from a loose topsoil to a dense subsoil. Shoot growth responded correspondingly.

One aspect had not yet been studied, viz. the influence of the depth of a compacted layer. In literature little was found about this topic. Lowry et al. (1970) give an example only with 10,20 and $30 \mathrm{~cm}$ depth treatments and various bulk densities. In this experiment it was found that final plant height and yield of seed cotton were reduced as soil bulk density or penetrometer resistance increased. Growth rate and yield were less on the $10 \mathrm{~cm}$ depth-to-pan treatment than on the 20 or $30 \mathrm{~cm}$ depth treatments. A restricted water supply due to limited rooting volume was seen as probably the principal factor causing reduced yield of cotton growing on higher strength soil pans.

The present paper gives the results of an experiment carried out for the purpose of studying the root and shoot development in profiles with compacted subsoils at various depths and moisture conditions at the juncture of non-compacted topsoil and compacted subsoil as similar as possible.

\section{Materials and methods}

The experiment was carried out in a similar way as foregoing ones with artificial profiles in tubes. These tubes were filled in different ways with the same kind of soil and were placed in vessels that were filled with water to a distinct height.

The diameter of these tubes was $20 \mathrm{~cm}$, the height $100 \mathrm{~cm}$. The sandy soil which was used had a humus content of $4.2 \%, \mathrm{pH}-\mathrm{KCl}$ was 6.6. Before filling ample quantities of fertilizer were mixed through the soil.

The profile types in the experiment were:

a. $23 \mathrm{~cm}$ loose topsoil on $75 \mathrm{~cm}$ dense subsoil. This profile resembles a normally ploughed agricultural soil.

b. $43 \mathrm{~cm}$ loose topsoil on $55 \mathrm{~cm}$ dense subsoil

c. $63 \mathrm{~cm}$ loose topsoil on $35 \mathrm{~cm}$ dense subsoil

d. $98 \mathrm{~cm}$ loose soil

resembling agricultural soils subsoiled to the indicated depth

The loose soil had a bulk density of 1.34 and a total pore volume of $48 \%$, the dense soil of 1.55 and $40 \%$, respectively.

The top $2 \mathrm{~cm}$ of the tubes was not filled with soil but with plastic granules in order to restrict evaporation from the soil.

To make sure that moisture conditions at the juncture between the loose topsoil and the dense subsoil were identical, the water-tables were established at the depths of 55, 75,95 and $95 \mathrm{~cm}$ below the upper rim of the tubes. Water was given on top of the soil in the period from 22 March to 3 July in order to avoid permanent desiccation of the topsoil. Moreover, water in the vessels was replenished more or less regularly during the period from 25 May to 21 June. Total water consumption per tube can be calculated from these data.

Per tube two selected seeds of oats were sown on 10 March. After emergence one of the plants was removed. All plants grew regularly. 
The experiment was laid out in six replicates. Samplings were scheduled in six growth stages:

1. initial tillering or nodal root formation (25 April);

2. 6th leaf stage (8 May);

3. last leaf visible ( 23 May);

4. just before panicle emergence (5 June);

5. early flowering (19 June);

6. only shoot weights were collected from the maturing plants on 3 July.

Samplings were carried out in duplicate, one root system being washed out and photographed, dried and weighed, one profile being cut in $5-\mathrm{cm}$ layers after which the roots were washed out, dried and weighed. Shoots were also dried and weighed.

\section{Results and discussion}

The results are summarized in Fig. 1-6 and Table 1-4. Pictures of the shoots and the root systems of subsequent samplings are given in Fig. 1-3. These figures show that differences in root growth occurred already in the earliest growth stage that was sampled. Most striking were the differences in rooting depth. It is worth mentioning that the maximum rooting depth in this stage was hardly exceeded in later stages. The pictures show clearly that rooting depth was mainly dependent upon the thickness of

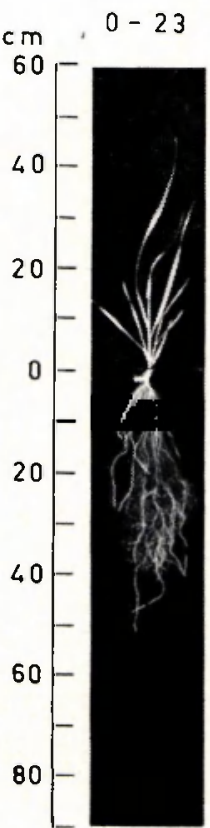

a

$$
0-43
$$

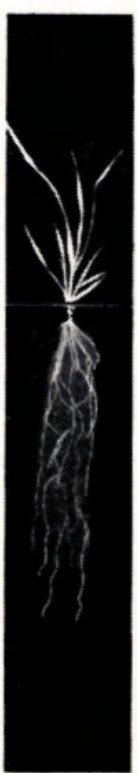

b

$$
0-63
$$

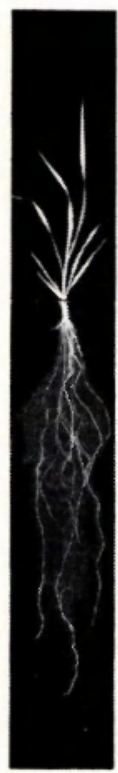

C
$0-98 \mathrm{~cm}$

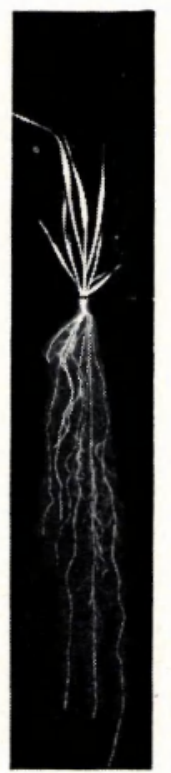

d

Fig. 1. Shoots and roots of the plants on 25 April (1st sampling). 


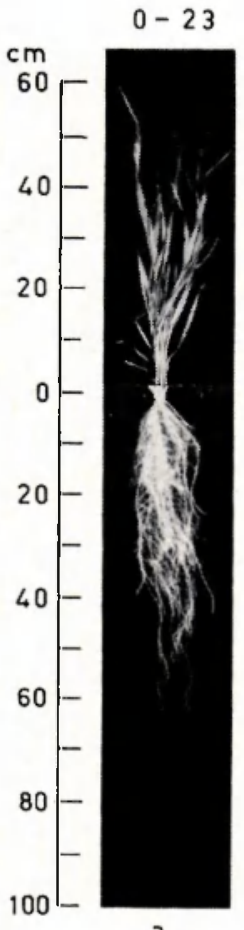

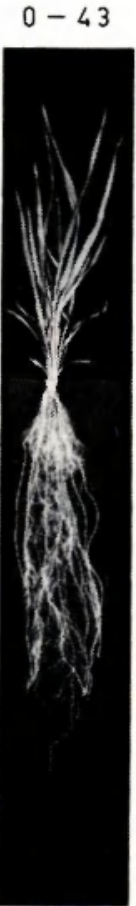

b

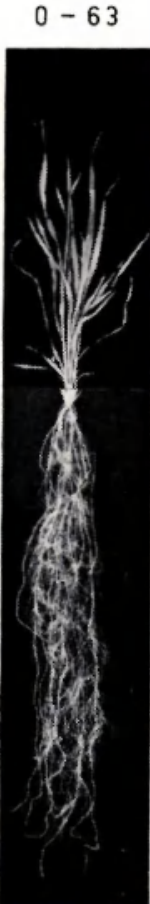

C

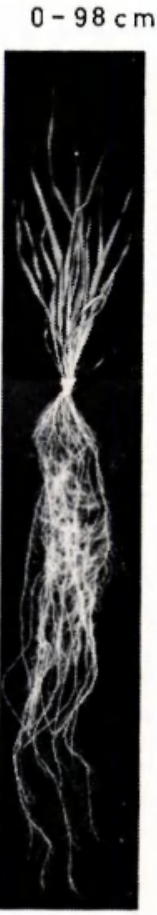

d

Fig. 2. Shoots and roots of the plants on 8 May (2nd sampling).

the loose topsoil. In the heterogeneous profiles penetration of roots in the dense subsoil ended always at a certain distance above the water-table. However, although density of this subsoil in these three profiles as well as water and air conditions at the border between loose topsoil and dense subsoil at the onset of the experiment were identical, root penetration tended to be shallower proportional to the increasing depth of the loose topsoil as appeared from the washed root systems. This suggests that roots at a shallower depth had a greater penetrating power than those in deeper layers. This has been seen also in earlier investigations. It may be assumed that the water-table has played a part in determining ultimate depth of rooting. If so, this may have been effectuated in the heterogeneous profiles with $23 \mathrm{~cm}$ loose topsoil a root stop at about $3 \mathrm{~cm}$ above the water-table.

Only in the homogeneous loose profiles roots penetrated in the soil water. It is suggested that this was possible due to a high oxygen content of the water owing to the shallow height of the water in the vessel. That soil strength has influenced root penetration is shown by comparison of Fig. 1-3 (cd), where with the same water-table the root penetration in the profile with a loose topsoil of $63 \mathrm{~cm}$ was shallower than in the homogeneous profile. Differences in shoot growth were less clear. Table 1 shows, however, that shoot weights on the two profiles with the thinnest loose topsoil exceeded those on the thicker ones, beginning in the stage just before panicle emergence (5 June). This was contrary to the findings of Lowry et al. (1970), but this can probably be 
EFFECT OF SOIL COMPACTION ON ROOT AND SHOOT GROWTH OF OATS

$0-23$

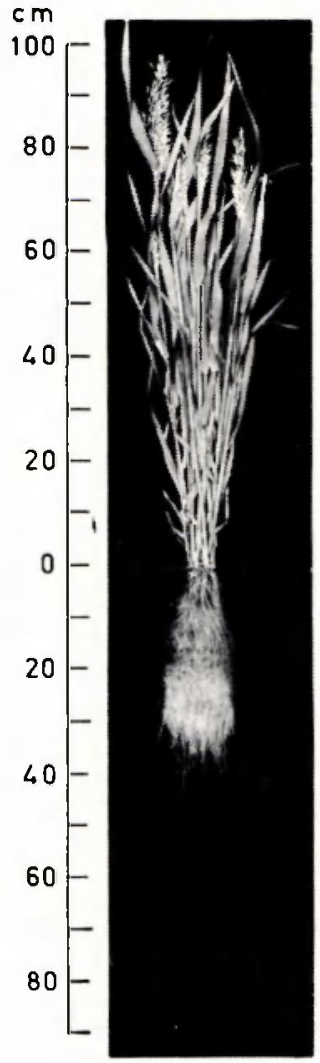

$a$
$0-43$

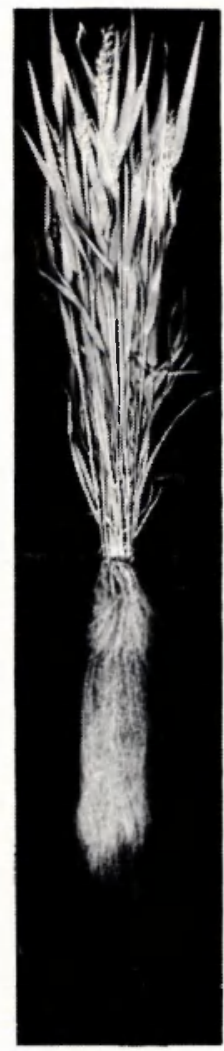

b
$0-63$

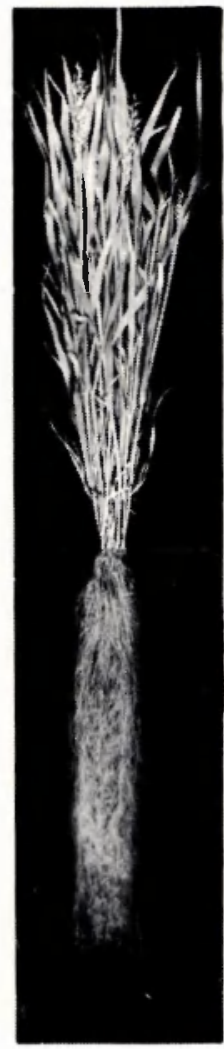

C
$0-98 \mathrm{~cm}$

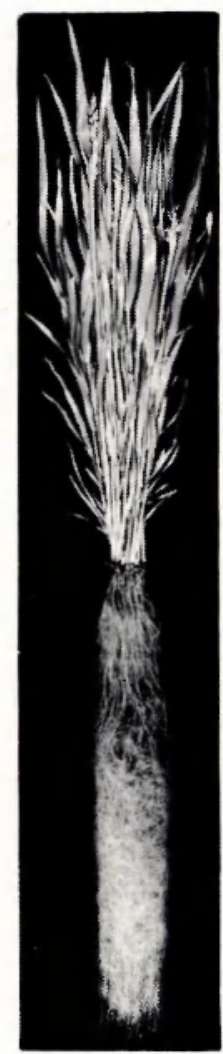

d

Fig. 3. Shoots and roots of the plants on 19 June (5th sampling).

Table 1. Average shoot weights (g).

\begin{tabular}{|c|c|c|c|c|}
\hline \multirow[t]{2}{*}{$\overline{\text { Dates }}$} & \multicolumn{4}{|c|}{ Height of loose toplayers $(\mathrm{cm})$} \\
\hline & 23 & 43 & 63 & 98 \\
\hline 25 April & 0.40 & 0.32 & 0.31 & 0.38 \\
\hline 8 May & 2.46 & 2.42 & 2.48 & 2.54 \\
\hline 23 May & 11.82 & 13.08 & 11.87 & 12.91 \\
\hline 5 June & 39.39 & 39.43 & 36.05 & 37.24 \\
\hline 19 June & $96.11 *$ & 98.96 & 88.71 & 89.70 \\
\hline 3 July & $119.15^{* *}$ & 132.46 & 109.09 & 99.42 \\
\hline Total & 269.33 & 286.67 & 248.51 & 242.19 \\
\hline
\end{tabular}

\footnotetext{
* Single observation (poor duplicate plant first recorded on 4 April).

** Single observation due to early death of duplicate plant.
} 
A. $0-23 \mathrm{~cm}$ loose

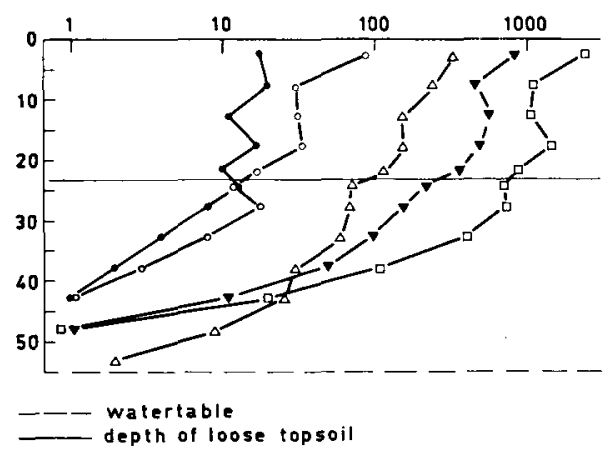

C. $0-63 \mathrm{~cm}$ loose

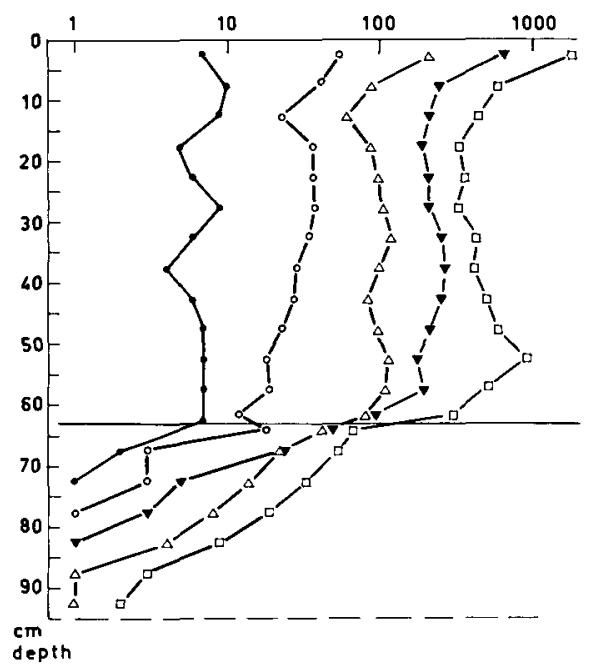

Fig. 4. Root weights per layer (mg).
B. $0-43 \mathrm{~cm}$ loose

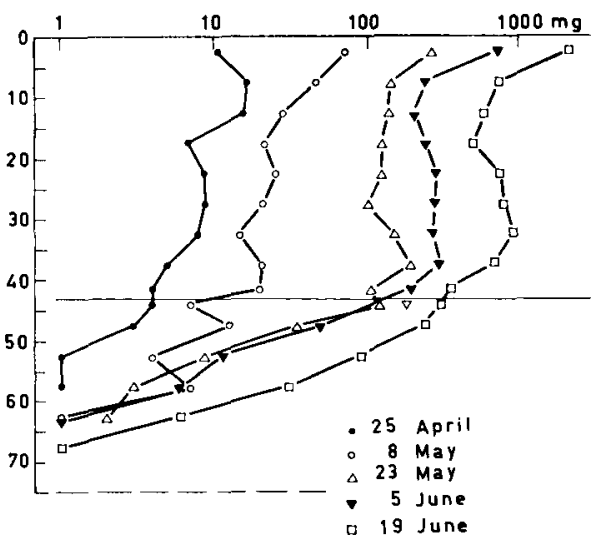

D. $0-98 \mathrm{~cm}$ loose

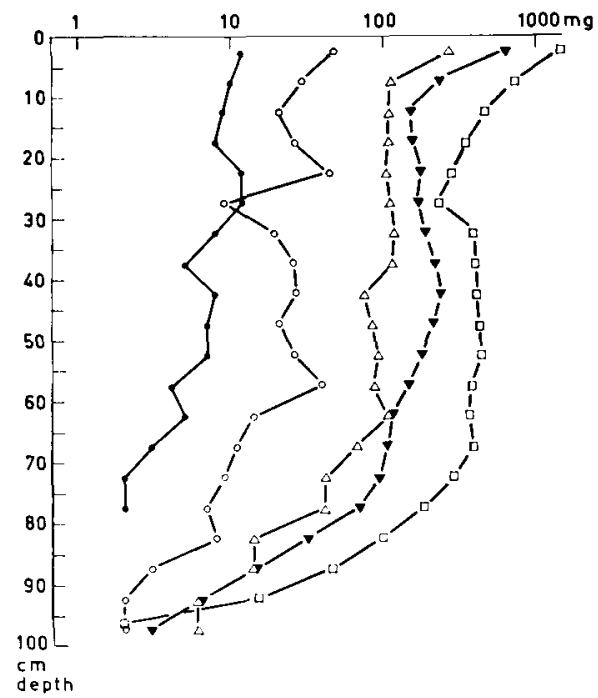

attributed to the high water-table of the two profiles with the thinnest loose topsoil in our experiment.

Fig. 4 gives the root weights in soil layers of $5 \mathrm{~cm}$ thickness in the various profiles in five consecutive growth stages. It is clear that in general root weights increased in all layers until the flowering stage. Moreover, root weights decreased rapidly below the transition from loose topsoil to dense subsoil. This is particularly clear when the root weights are compared with those in the homogeneous loose profile in Fig. 4. Root weights in the loose topsoil and in the dense subsoil of the various profiles are given in Table 2A. Here they are compared with the corresponding layers of the homo- 
Table 2. Comparison of root growth in corresponding layers in heterogeneous and homogeneous profiles.

\begin{tabular}{|c|c|c|c|c|c|c|c|c|c|}
\hline \multirow[t]{2}{*}{ Date } & \multirow{2}{*}{$\begin{array}{l}\text { Profile } \\
\text { layers } \\
(\mathrm{cm})\end{array}$} & \multicolumn{2}{|c|}{$\begin{array}{l}\text { Profiles with } \\
\text { loose soil }\end{array}$} & \multirow{2}{*}{$\begin{array}{l}\text { Profile } \\
\text { layers } \\
(\mathrm{cm})\end{array}$} & \multicolumn{2}{|c|}{$\begin{array}{l}\text { Profiles with } \\
\text { loose soil }\end{array}$} & \multirow{2}{*}{$\begin{array}{l}\text { Profile } \\
\text { layers } \\
(\mathrm{cm})\end{array}$} & \multicolumn{2}{|c|}{$\begin{array}{l}\text { Profiles with } \\
\text { loose soil }\end{array}$} \\
\hline & & $\begin{array}{l}0-23 \\
\mathrm{~cm}\end{array}$ & $\begin{array}{l}0.98 \\
\mathrm{~cm}\end{array}$ & & $\begin{array}{l}0-43 \\
\mathrm{~cm}\end{array}$ & $\begin{array}{l}0-98 \\
\mathrm{~cm}\end{array}$ & & $\begin{array}{l}0-63 \\
\mathrm{~cm}\end{array}$ & $\begin{array}{l}0-98 \\
\mathrm{~cm}\end{array}$ \\
\hline \multicolumn{10}{|c|}{ A. Weights (mg) } \\
\hline 25 April & $\begin{array}{r}0-23 \\
23-98 \\
\text { total }\end{array}$ & $\begin{array}{r}76 \\
29 \\
105\end{array}$ & $\begin{array}{r}51 \\
67 \\
118\end{array}$ & $\begin{array}{r}0-43 \\
43-98\end{array}$ & $\begin{array}{l}86 \\
10 \\
96\end{array}$ & $\begin{array}{r}84 \\
3 \ddot{4} \\
118\end{array}$ & $\begin{array}{r}0-63 \\
63-98\end{array}$ & $\begin{array}{r}87 \\
6 \\
93\end{array}$ & $\begin{array}{r}107 \\
11 \\
118\end{array}$ \\
\hline 8 May & $\begin{array}{c}0-23 \\
23-98 \\
\text { total }\end{array}$ & $\begin{array}{r}196 \\
43 \\
239\end{array}$ & $\begin{array}{l}171 \\
221 \\
392\end{array}$ & $\begin{array}{r}0-43 \\
43-98\end{array}$ & $\begin{array}{r}279 \\
33 \\
312\end{array}$ & $\begin{array}{l}249 \\
143 \\
392\end{array}$ & $\begin{array}{r}0-63 \\
63-98\end{array}$ & $\begin{array}{r}394 \\
26 \\
420\end{array}$ & $\begin{array}{r}350 \\
42 \\
392\end{array}$ \\
\hline 23 May & $\begin{array}{c}0-23 \\
23-98 \\
\text { total }\end{array}$ & $\begin{array}{r}1021 \\
275 \\
1296\end{array}$ & $\begin{array}{r}729 \\
985 \\
1714\end{array}$ & $\begin{array}{r}0-43 \\
43-98\end{array}$ & $\begin{array}{r}1408 \\
175 \\
1583\end{array}$ & $\begin{array}{r}1148 \\
566 \\
1714\end{array}$ & $\begin{array}{r}0-63 \\
63-98\end{array}$ & $\begin{array}{r}1381 \\
92 \\
1473\end{array}$ & $\begin{array}{r}1525 \\
189 \\
1714\end{array}$ \\
\hline 5 June & $\begin{array}{c}0-23 \\
23-98 \\
\text { total }\end{array}$ & $\begin{array}{r}2737 \\
543 \\
3280\end{array}$ & $\begin{array}{l}1392 \\
1807 \\
3199\end{array}$ & $\begin{array}{r}0-43 \\
43-98\end{array}$ & $\begin{array}{r}2826 \\
264 \\
3090\end{array}$ & $\begin{array}{r}2223 \\
976 \\
3199\end{array}$ & $\begin{array}{r}0-63 \\
63-98\end{array}$ & $\begin{array}{r}3245 \\
81 \\
3326\end{array}$ & $\begin{array}{r}2874 \\
325 \\
3199\end{array}$ \\
\hline 19 June & $\begin{array}{l}0-23 \\
23-98 \\
\text { total }\end{array}$ & $\begin{array}{l}6927 \\
2000 \\
8927\end{array}$ & $\begin{array}{l}3385 \\
4121 \\
7506\end{array}$ & $\begin{array}{r}0-43 \\
43-98\end{array}$ & $\begin{array}{r}7739 \\
703 \\
8442\end{array}$ & $\begin{array}{l}4831 \\
2675 \\
7506\end{array}$ & $\begin{array}{r}0-63 \\
63-98\end{array}$ & $\begin{array}{r}7711 \\
188 \\
7899\end{array}$ & $\begin{array}{l}6472 \\
1034 \\
7506\end{array}$ \\
\hline \multicolumn{10}{|c|}{ B. Percentages } \\
\hline 25 April & $\begin{array}{r}0-23 \\
23-98\end{array}$ & $\begin{array}{l}72.3 \\
27.7\end{array}$ & $\begin{array}{l}43.4 \\
56.6\end{array}$ & $\begin{array}{r}0-43 \\
43-98\end{array}$ & $\begin{array}{l}89.7 \\
10.3\end{array}$ & $\begin{array}{l}71.5 \\
28.5\end{array}$ & $\begin{array}{r}0-63 \\
63-98\end{array}$ & $\begin{array}{r}93.3 \\
6.7\end{array}$ & $\begin{array}{r}91.2 \\
8.8\end{array}$ \\
\hline 8 May & $\begin{array}{r}0-23 \\
23-98\end{array}$ & $\begin{array}{l}82.0 \\
18.0\end{array}$ & $\begin{array}{l}43.3 \\
56.7\end{array}$ & $\begin{array}{r}0-43 \\
43-98\end{array}$ & $\begin{array}{l}89.3 \\
10.7\end{array}$ & $\begin{array}{l}63.8 \\
36.2\end{array}$ & $\begin{array}{r}0-63 \\
63-98\end{array}$ & $\begin{array}{r}93.9 \\
6.1\end{array}$ & $\begin{array}{l}89.4 \\
10.6\end{array}$ \\
\hline 23 May & $\begin{array}{r}0-23 \\
23-98\end{array}$ & $\begin{array}{l}78.7 \\
21.3\end{array}$ & $\begin{array}{l}42.6 \\
57.4\end{array}$ & $\begin{array}{r}0-43 \\
43-98\end{array}$ & $\begin{array}{l}88.9 \\
11.1\end{array}$ & $\begin{array}{l}67.1 \\
32.9\end{array}$ & $\begin{array}{r}0-63 \\
63-98\end{array}$ & $\begin{array}{r}93.8 \\
6.2\end{array}$ & $\begin{array}{l}89.2 \\
10.8\end{array}$ \\
\hline 5 June & $\begin{array}{r}0-23 \\
23-98\end{array}$ & $\begin{array}{l}83.4 \\
16.6\end{array}$ & $\begin{array}{l}43.5 \\
56.5\end{array}$ & $\begin{array}{r}0-43 \\
43-98\end{array}$ & $\begin{array}{r}91.5 \\
8.5\end{array}$ & $\begin{array}{l}69.5 \\
30.5\end{array}$ & $\begin{array}{r}0-63 \\
63-98\end{array}$ & $\begin{array}{r}97.1 \\
2.9\end{array}$ & $\begin{array}{l}89.8 \\
10.2\end{array}$ \\
\hline 19 June & $\begin{array}{r}0-23 \\
23-98\end{array}$ & $\begin{array}{l}77.7 \\
22.3\end{array}$ & $\begin{array}{l}45.0 \\
55.0\end{array}$ & $\begin{array}{r}0-43 \\
43-98\end{array}$ & $\begin{array}{r}91.6 \\
8.4\end{array}$ & $\begin{array}{l}64.3 \\
35.7\end{array}$ & $\begin{array}{r}0-63 \\
63-98\end{array}$ & $\begin{array}{r}97.6 \\
2.4\end{array}$ & $\begin{array}{l}86.1 \\
13.9\end{array}$ \\
\hline
\end{tabular}

geneous profile. Through the whole growth period the root weights in the loose topsoil of the heterogeneous profiles were higher than in the comparable layers of the homogeneous ones. Those in the dense subsoil of the heterogeneous profiles were lower than in the corresponding loose subsoil of the homogeneous ones. Up to and including 23 May - when the last leaf had become visible - the total root weights in the homogeneous profiles were higher than in the heterogeneous ones. After this date the root weights in the upper portions of the heterogeneous profiles increased considerably more than those in the corresponding layers of the homogeneous ones (Fig. 5) and although root weights in the subsoil were higher in the homogeneous profiles, this resulted in higher total root weights in the former ones. This was to a certain extent concurrent with the shoot weights (Table 1), indicating that the topsoil roots in the heterogeneous profiles in this experiment were more important for plant growth than 

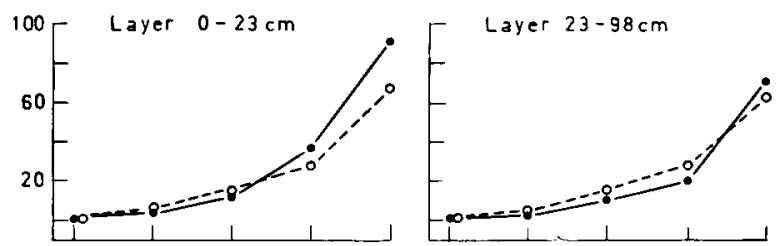

Fig. 5. Relative root weights.

- profile with $23 \mathrm{~cm}$ loose topsoil
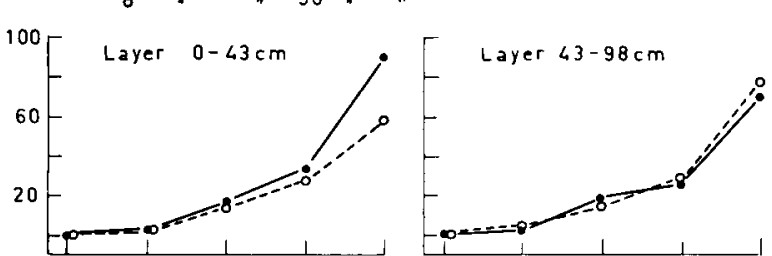

- profile with $43 \mathrm{~cm}$ loose topsorl

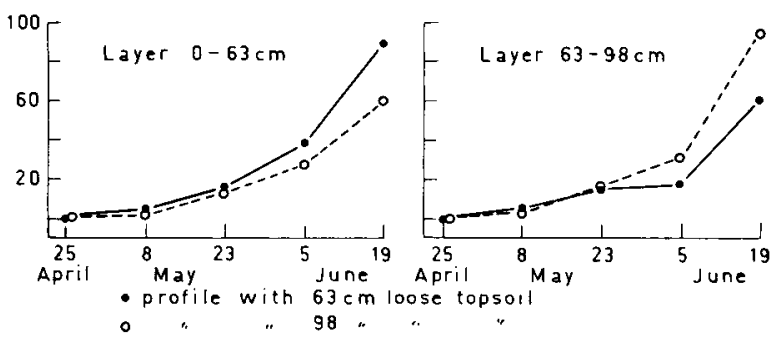

those in the subsoil, leading to a better shoot growth per gramme of roots (higher shoot/root ratio).

The relative distribution of the roots in the topsoil and subsoil of the profiles changed comparatively little. This is shown by Table $2 \mathrm{~B}$ where the percentages of these layers during the growth period of the plant are given. The changes were particularly small in the homogeneous profiles and to a lesser extent in the profiles with a loose topsoil of 63 or $43 \mathrm{~cm}$.

The direct response of root weights to the sudden transition from loose to dense soil can be seen by comparison of the samples of the layers just above and below the transition, which had a thickness of 2 and $3 \mathrm{~cm}$ respectively. Therefore these samples have been discarded and been replaced by those from the adjoining layers with a thickness of $5 \mathrm{~cm}$. The results are given in Table 3, where totals of the five samplings are given. The conclusion can be drawn from these figures that root weights decreased much more at a transition from loose to dense soil than in the corresponding layers of the homogeneous loose profile. However, roots responded much more as the depth of the loose topsoil was greater, as is shown by the relative figures. The decrease in root weight may be caused by reduction in the number of roots penetrating the dense subsoil, or by decrease of branching. Therefore numbers of root axes above and below the transition have been counted (Table 4). It is evident from these figures that these numbers decreased also at the transition from loose to dense but to a much smaller extent than the root weights. This leads to the conclusion that the decreases found 
Table 4. Response of root numbers on transition from loose topsoil to dense subsoil.

\begin{tabular}{|c|c|c|c|c|c|c|c|c|c|}
\hline & \multirow{2}{*}{$\begin{array}{l}\text { Profile } \\
\text { layers } \\
(\mathrm{cm})\end{array}$} & \multicolumn{2}{|c|}{$\begin{array}{l}\text { Profiles with } \\
\text { loose soil }\end{array}$} & \multirow{2}{*}{$\begin{array}{l}\text { Profile } \\
\text { layers } \\
(\mathrm{cm})\end{array}$} & \multicolumn{2}{|c|}{$\begin{array}{l}\text { Profiles with } \\
\text { loose soil }\end{array}$} & \multirow{2}{*}{$\begin{array}{l}\text { Profile } \\
\text { layers } \\
(\mathrm{cm})\end{array}$} & \multicolumn{2}{|c|}{$\begin{array}{l}\text { Profiles with } \\
\text { loose soil }\end{array}$} \\
\hline & & $\begin{array}{l}0-23 \\
\mathrm{~cm}\end{array}$ & $\begin{array}{l}0-98 \\
\mathrm{~cm}\end{array}$ & & $\begin{array}{l}0-43 \\
\mathrm{~cm}\end{array}$ & $\begin{array}{l}0-98 \\
\mathrm{~cm}\end{array}$ & & $\begin{array}{l}0-63 \\
\mathrm{~cm}\end{array}$ & $\begin{array}{l}0-98 \\
\mathrm{~cm}\end{array}$ \\
\hline $\begin{array}{l}\text { Totals of } 19 \text { June } \\
\text { and } 3 \text { July }\end{array}$ & $\begin{array}{l}15-20 \\
25-30\end{array}$ & $\begin{array}{l}445 \\
306\end{array}$ & $\begin{array}{l}452 \\
307\end{array}$ & $\begin{array}{l}35-40 \\
45-50\end{array}$ & $\begin{array}{l}324 \\
262\end{array}$ & $\begin{array}{l}263 \\
236\end{array}$ & $\begin{array}{l}55-60 \\
65-70\end{array}$ & $\begin{array}{l}287 \\
209\end{array}$ & $\begin{array}{l}221 \\
188\end{array}$ \\
\hline Relative & $\begin{array}{l}15-20 \\
25-30\end{array}$ & $\begin{array}{r}100 \\
69\end{array}$ & $\begin{array}{r}100 \\
68\end{array}$ & $\begin{array}{l}35-40 \\
45-50\end{array}$ & $\begin{array}{r}100 \\
81\end{array}$ & $\begin{array}{r}100 \\
90\end{array}$ & $\begin{array}{l}55-60 \\
65-70\end{array}$ & $\begin{array}{r}100 \\
73\end{array}$ & $\begin{array}{r}100 \\
85\end{array}$ \\
\hline
\end{tabular}

Table 3. Response of root weights (mg) on transition from loose topsoil to dense subsoil.

\begin{tabular}{|c|c|c|c|c|c|c|c|c|c|}
\hline & \multirow{2}{*}{$\begin{array}{l}\text { Profile } \\
\text { layers } \\
(\mathrm{cm})\end{array}$} & \multicolumn{2}{|c|}{$\begin{array}{l}\text { Profiles with } \\
\text { loose soil }\end{array}$} & \multirow{2}{*}{$\begin{array}{l}\text { Profile } \\
\text { layers } \\
(\mathrm{cm})\end{array}$} & \multicolumn{2}{|c|}{$\begin{array}{l}\text { Profiles with } \\
\text { loose soil }\end{array}$} & \multirow{2}{*}{$\begin{array}{l}\text { Profile } \\
\text { layers } \\
(\mathrm{cm})\end{array}$} & \multicolumn{2}{|c|}{$\begin{array}{l}\text { Profiles with } \\
\text { loose soil }\end{array}$} \\
\hline & & $\begin{array}{l}0-23 \\
\mathrm{~cm}\end{array}$ & $\begin{array}{l}0-98 \\
\mathrm{~cm}\end{array}$ & & $\begin{array}{l}0-43 \\
\mathrm{~cm}\end{array}$ & $\begin{array}{l}0-98 \\
\mathrm{~cm}\end{array}$ & & $\begin{array}{l}0-63 \\
\mathrm{~cm}\end{array}$ & $\begin{array}{l}0-98 \\
\mathrm{~cm}\end{array}$ \\
\hline $\begin{array}{l}\text { Totals of five } \\
\text { sampling dates }\end{array}$ & $\begin{array}{l}15-20 \\
25-30\end{array}$ & $\begin{array}{l}2156 \\
1009\end{array}$ & $\begin{array}{l}594 \\
469\end{array}$ & $\begin{array}{l}35-40 \\
45-50\end{array}$ & $\begin{array}{r}1235 \\
356\end{array}$ & $\begin{array}{l}682 \\
690\end{array}$ & $\begin{array}{l}55-60 \\
65-70\end{array}$ & $\begin{array}{l}863 \\
104\end{array}$ & $\begin{array}{l}600 \\
545\end{array}$ \\
\hline Relative & $\begin{array}{l}15-20 \\
25-30\end{array}$ & $\begin{array}{r}100 \\
48\end{array}$ & $\begin{array}{r}100 \\
79\end{array}$ & $\begin{array}{l}35-40 \\
45-50\end{array}$ & $\begin{array}{r}100 \\
29\end{array}$ & $\begin{array}{l}100 \\
101\end{array}$ & $\begin{array}{l}55-60 \\
65-70\end{array}$ & $\begin{array}{r}100 \\
12\end{array}$ & $\begin{array}{r}100 \\
91\end{array}$ \\
\hline
\end{tabular}

at the transition from loose topsoil to dense subsoil were mainly due to decreases in root branching. It cannot be concluded from the available data whether this was a diminution of the numbers of branch roots or of the length and probably the diameter of these or both.

The shoot/root ratios are given in Fig. 6. It is clear that those on the two profiles

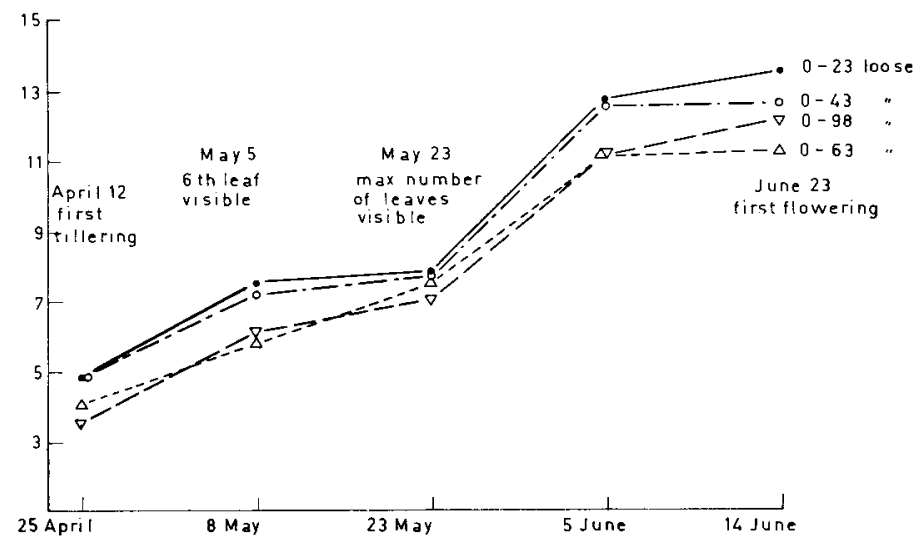

Fig. 6. Average shoot/root ratios. 
with the thinnest loose topsoil were highest during the whole growth period of the plants. This is an indication that prevailing uptake conditions were more favourable on the profiles with 23 and $43 \mathrm{~cm}$ loose topsoil. Notwithstanding the restricted root development these plants have been able to absorb water and minerals in liberal amounts, as was also found in an earlier experiment (Schuurman, 1971b). This was confirmed by the water consumption measurements.

\section{References}

Lowry, F. E., H. M. Taylor \& M. G. Huck, 1970. Growth rate and yield of cotton as influenced by depth and bulk density of soil pans. Proc. Soil Sci. Soc. Am. 34: 306-309.

Schuurman, J. J., 1965. Influence of soil density on root development and growth of oats. Pl. Soil 22: 352-374.

Schuurman, J. J., 1968. Effects of soil density on root and top growth of oats. Proc. Int. Sci. Symp. (June 1966, Brno, Csechoslovakia): 103-120.

Schuurman, J. J., 1971a. Effects of density of top and subsoil on root and top growth of oats. Z.Acker- u. PflBau 134: 185-199.

Schuurman, J. J., 1971b. Effects of supplemental fertilization on growth of oats with restricted root development. Z.Acker- u. PflBau 133: 315-320.

Schuurman, J. J. \& J. J. H. de Boer, 1971. De invloed van de dichtheid van zandgrond op het verloop van wortelgroei en bovengrondse groei van haver. Versl. landbouwk. Onderz. 751: $26 \mathrm{pp}$. 